慣性核融合炉のための液体金属衝撃波実験

染谷和良, 宮健三

( 東大·工・原子力工学研究施設)

( 1983 年 7 月 16 日 受理)

\title{
Experiments of Electron Beam Induced Shock Wave to Simulate the Pulsive Response of an ICF Reactor with Liquid Metal Wall
}

\author{
Kazuyoshi Someya and Kenzo Miya
}

(Received July 16, 1983)

\begin{abstract}
In an Inertial Confinement Fusion (ICF) reactor with liquid lithium curtain, energetic charged particles and fast neutrons from a microexplosion give the impact and the pulsive load to the liquid lithium layer and drive the shock waves. To study the phenomena and the related problems of the structural mechanics, simulation experiments using liquid $\mathrm{Hg}$ irradiated by electron beam were carried out. Measurements and analysis of the shock wave are described in this article.
\end{abstract}

1. 目 的

慣性閉じ込め核融合炉の場合, ペレット爆縮時のイオン飛散, 点火時の高速中性子及び $\alpha$ 粒子の飛 散によって，冷却材である液体金属リシウムのウォールには，熱負荷が加わり，熱衝撃現象が生じる ととが考えられる。との現象を把握するととは, 炉容器の構造設計上不可欠のととである。そとで, 我々は, 試料として水銀を用い, てれにライナックによる電子線を入射して, 容器内に発生する衝撃 波（圧力波）を測定するととを先ず目的とした。

Nuclear Engineering Research Laboratory Faculty of Engineering University of Tokyo Tokai, Ibaraki 319-11 


\section{2. 実験方法}

(1) 試験体

試験体の形状及び寸法を図 1 亿示す。試験体はSUS 304 製の円筒容器で, 溶接部の無い, 削り出 し加工した一体ものである。盲フランジの蓋をするてとにより, 密封容器となる。容積は, 圧力変換 器を取り付けた場合が約 $91 \mathrm{~cm}^{3}$, ダイヤフラムを取り付けた場合が約 $86 \mathrm{~cm}^{3}$ である。との容器に水 銀を満たし, 図 1 のエア抜き孔より, ほぼ完全に空気を抜くことができる。エレクトロン・ビームは, 図中の介印の方向から打ち込んだ。打ち込まれたエレクトロンビームは, $2 \mathrm{~mm}$ 嬮の容器壁を透過し
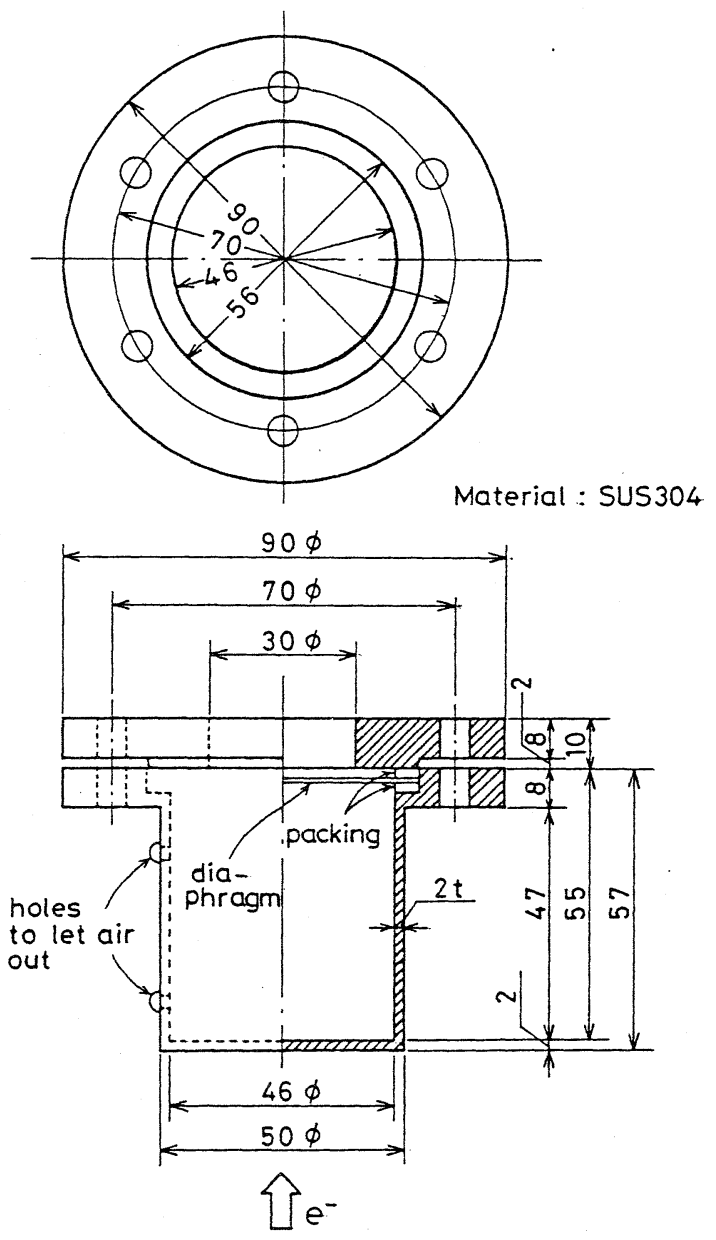

図 1. 円筒容器の形状と寸法 


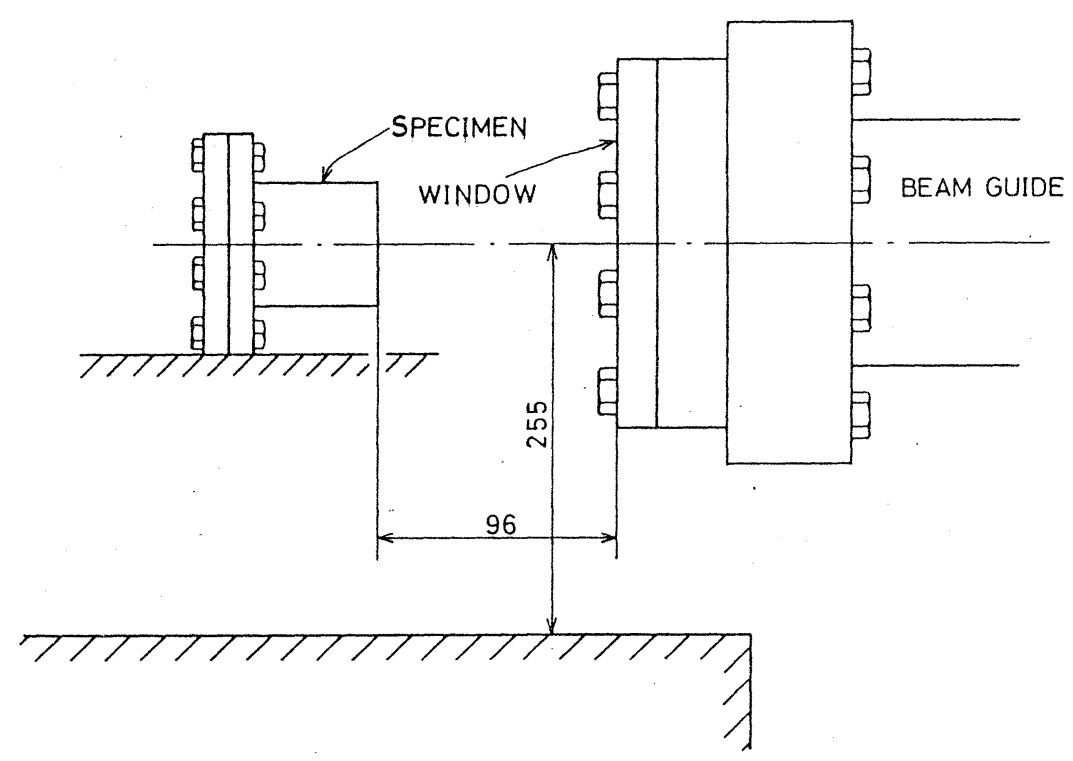

図 2、照射系と試験体の設置状況

て, 水銀中に吸収させる。概算に上り, 水銀中の最大飛程 は約 $7 \mathrm{~mm}$ ( $25 \mathrm{MeV}$ の電子の場合)であり, 容器の長さを $50 \mathrm{~mm}$ とすれば, 打ち込まれたエレクトロンは, 全量吸 収されるものとした。また, 水銀中に発生する圧力波が伝 播しつつ, 測定端で減衰するととを考慮して, 容器は図の ような寸法となった。パッキンは，アマルガムの生成を考 慮して,アスベスト・パッキンを用いた。

との試験体を, 図 2 亿示す位置に設置し, 照射を行なった。 (2) 測定法

纴力の測定は, 半導体圧力変換器 (豊田工機製) を用い を場合と, 手製のダィヤフラム式検出器を用いた場合の 2

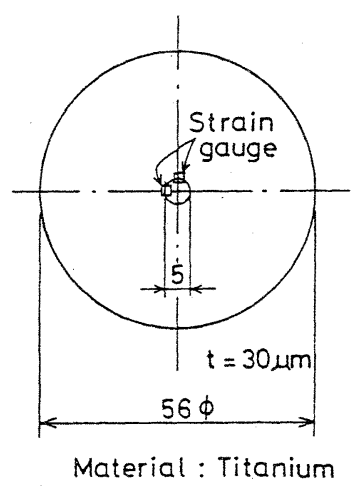

図3、ダイヤフラムおよび ケージ貼付位置 通りの方法によった。図1はダイヤフラム式検出器を取り付けた場合の図で,ダイヤフラムの詳細は, 図 3 亿示す。ダィヤフラムは, 厚さ $30 \mu \mathrm{m}$, 直径 $56 \mathrm{~mm}$ 中のチタン ( Ti ) 膜を用い, 乙れに図 3 に示 す位置に歪ゲージを貼付したものである。ゲージ長は $0.5 \mathrm{~mm}$ である。 

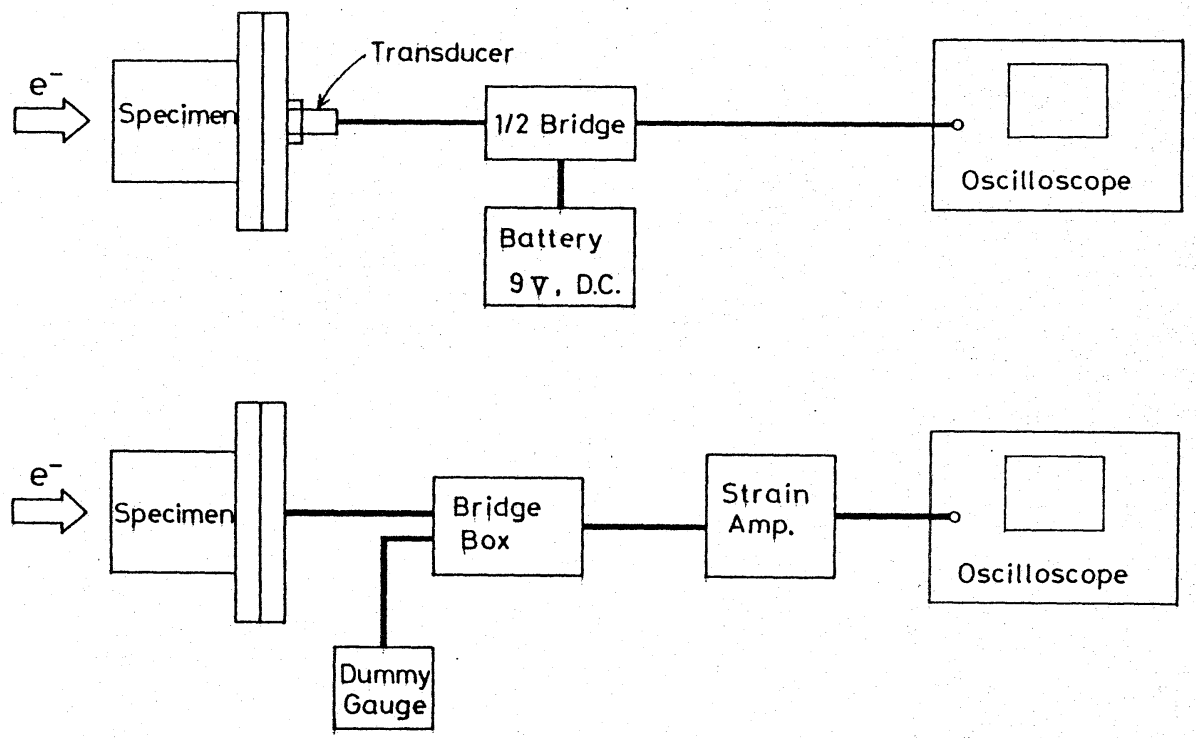

図 4 ．測定系ブロックダイヤグラム

測定系のブロックダイヤグラムを図 4 に示す。半導体圧力変換器を用いた場合は,ブリッヂの残り 2 辺と定電圧源（乾電池 $9 \mathrm{~V}$ ) を介して, 出力をオシロスコープにて観察した。ダイヤフラム式検出 器の場合は，2枚のダそーゲージとによりブリッヂを構成し，ブリッヂ・ボックス及びダイナミック． ストレインメータを介して, 出力をオシロスコープにて観察した。オシロスコープのスイープ用トリ ガは戔イナック側のマスタートリガ（Master Trig・）を用いた。

（3）試験条件

試験温度及び水銀の温度は, 室温 $\left(25^{\circ} \mathrm{C}\right)$ である。

ビーム条件は, エネルギ $25 \mathrm{MeV}$ ，ビームカレント $170 \mathrm{~mA}$ ，パルス幅 $4.5 \mu \mathrm{sec}$ で, one shot. 及び $3.25 \mathrm{pps}$ の繰返しと変化させた。ビームスポットの大きさは, ラドカラーによる観測の結果, 試験体入射面で約 $10 \mathrm{~mm} \phi$ であった。

\section{3. 実験結果}

(1) 半導体圧力変換器を用いた場合

先ず, 応答周波数の高い変換器 (固有振動数約 $100 \mathrm{kHz}$, 容量 $100 \mathrm{~kg} / \mathrm{cm}^{2}$ ) を用いた。乙のとき 
は，圧力計の容量が大きすぎて，圧力の変化が検出できなかった。

次に, 応答周波数よりも測定範囲に着目して, 容量 $10 \mathrm{~kg} / \mathrm{cm}^{2}$ (固有振動数約 $60 \mathrm{kH} \mathrm{z}$ ) のもの を用いた。Photo 1 は, ビーム条件がパルス幅 $4.5 \mu \mathrm{sec}$ で one shotのときの原信号である。水平 軸及び垂直軸のレンヂは，それぞれ $5 \mu \mathrm{sec} / \mathrm{div} ., 0.1 \mathrm{~V} / \mathrm{div}$.である。乙の写真からは，マスタ ートリガにて掃引開始後 $13 \mu \mathrm{sec}$ にて高圧パルサによるノイズが見られ，また $20 \mu \mathrm{sec}$ 後にはビーム 発射によるノイズが約 $1 \mu \mathrm{sec}$ の間見られる。その後は, 圧力変換器からの信号であろうと考えられ た。従って, 次にトリガ信号をライナック側で, ディレイ回路を介して遅延させ,ビーム発射による ノイズを消去し，ビーム発射以前をトリガ点として観測したものが，Photo 2 である。垂直軸を， $5 \mathrm{mV} /$ div. とPhoto 1 より感度を上げたにも拘らず, 振幅はそれ程大きくならなかった。てれは， オシロスコープの入力端子に $75 \Omega$ ターミネータを接栓したととにより，信号が減衰したためと思われる

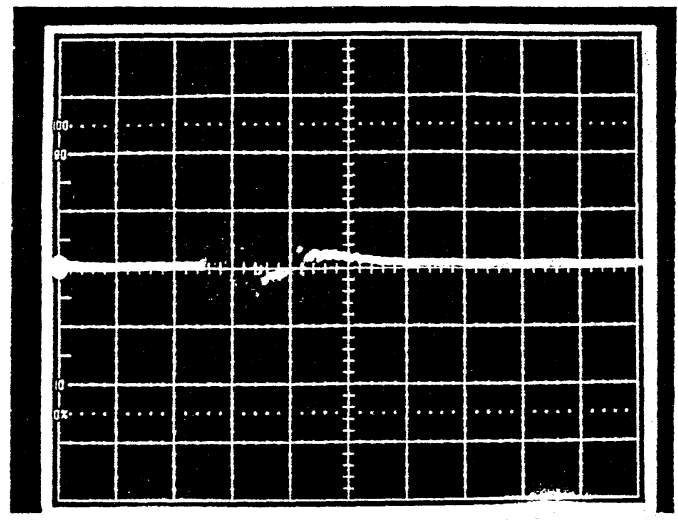

\section{Photo I}

王力变换器による原信号波形
水平䩜
$5 \mu \sec / \mathrm{div}$.
垂值軸
$0.1 \mathrm{~V} / \mathrm{div}$.
試 料 水 銀
王力变換器 R M S - 5 M
室 温

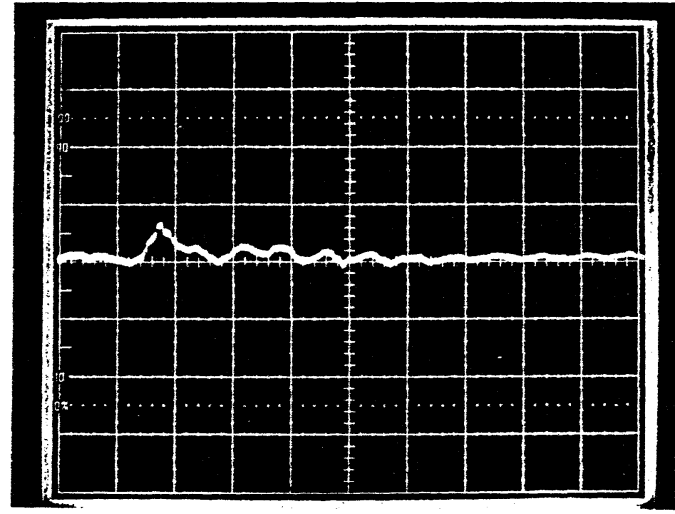

\section{Photo 2}

王力变換器による波形

水平軸 $5 \mu \mathrm{sec} / \mathrm{div}$.
垂直軸 $5 \mathrm{mV} / \mathrm{div}$.
ピーム条件
$4.5 \mu \mathrm{sec}$,
one shot
室 温


（減衰特性約- $4 \mathrm{~dB}$ )。Photo 2 の波形が信号であるか否かの確認の為, トリガの条件及び実験体系 を同一にして，図2 の試験体と照射㥶との間に，厚さ $50 \mathrm{~mm}$ の鉛ブロックを置いてビームを発射した。 その結果は, Photo 3 亿示すように, 何の信号もノィズも見られなかった。てれによって, Photo 2 の波形は, 圧力変換器からの信号であると判定した。

Photo 2 を見ると, 掃引開始後 $7 \mu \mathrm{sec}$ で立ち上がりが見られ,その後減衰振動を示した。種々の

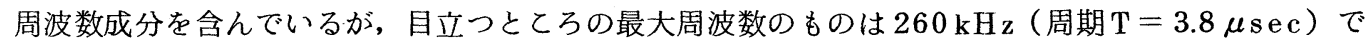
あった。てれは, 圧力変換器の固有振動数（カタログによると $60 \mathrm{kHz}$ )をはるかに越えていて, 応答 周波数からみて水銀中での圧力波信号としての信頼性がうすい。

次に，信号の全体像を見るため, 時間軸を $50 \mu \mathrm{sec} / \mathrm{div}$. としたものが, Photo 4 である。ての 写真より読みとれる周波数は $14.2 \mathrm{kHz}$ ( 周期 $\mathrm{T}=70 \mu \mathrm{sec}$ ) である。円筒容器の長さは約 $50 \mathrm{~mm}$ で
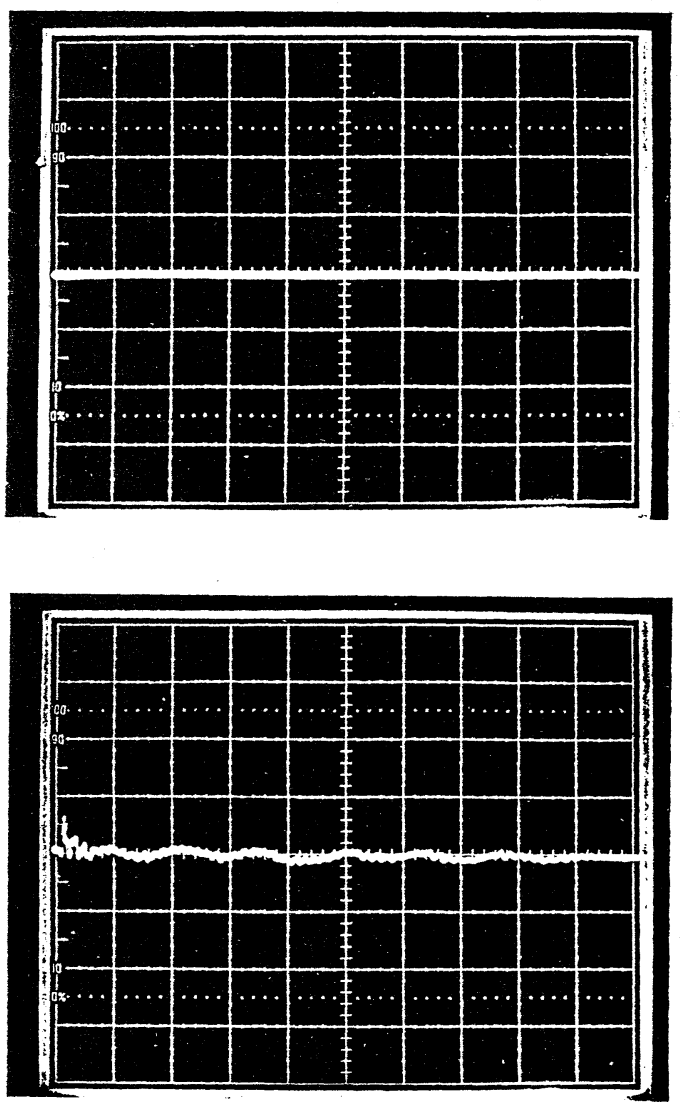

\section{Photo 3}

印力变換器による波形

( 鉛ブロック設置 )

水平軸 $10 \mu \mathrm{sec} / \mathrm{div}$.

垂直軸 $50 \mathrm{mV} / \mathrm{div}$.

ビーム条件

4. $5 \mu \mathrm{sec}$,

one shot

室 温

\section{Photo 4}

王力变換器による波形

$$
\begin{aligned}
& \text { 水平軸 } 50 \mu \mathrm{sec} / \mathrm{div} . \\
& \text { 垂直軸 } 5 \mathrm{mV} / \mathrm{div} . \\
& \text { ヒーーム条件 } \\
& \text { 4. } 5 \mu \mathrm{sec}, \\
& \text { one shot } \\
& \text { 室 温 }
\end{aligned}
$$


あるので, これより水銀中での波の速度 $\mathrm{v}$ を求めると，

$$
\mathrm{v}=\frac{0.05 \times 2}{70 \times 10^{-6}} \fallingdotseq 1430 \mathrm{~m} / \mathrm{sec}
$$

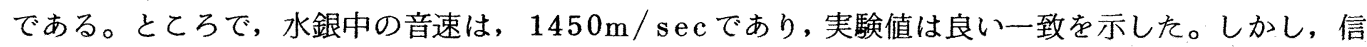
号として微弱であるので, 出力が更に大きく得られるように検討する必要がある。

(2) ダイヤフラム式検出器を用いた場合

ビーム条件は, 圧力変換器による場合と同様に, パルス幅 $4.5 \mu \mathrm{sec}$ で one shot とした。とのと きの, オシロスコープによる波形をPhoto 5 に示す。水平軸 $20 \mathrm{msec} / \mathrm{div}$., 垂直軸 $50 \mathrm{mV} / \mathrm{div}$. で周波数 $175 \mathrm{~Hz}$ ( 周期 $\mathrm{T}=5.7 \mathrm{~m} \mathrm{sec}$ ) の減衰振動を示した。しかし，乙れは水銀中の波の后播とし ては遅く,ダィヤフラムの固有振動ではないかと思われる。そてで, 周縁で固定された円板の横振動 として, 次式によりとのダイャフラムの固有振動数 $\mathrm{f}$ を求めてみる。ただし, $\mathrm{Ti}$ 膜の左右の媒質の違 いを無視した。

$$
\begin{aligned}
\mathrm{p}=\frac{10.21}{\mathrm{a}^{2}} \cdot \sqrt{\frac{\mathrm{D}}{\rho \mathrm{h}}}=2 \pi \mathrm{f} \\
\text { ここで } \mathrm{a}: \text { 半径 } \quad\left(=23 \times 10^{-3} \mathrm{~m}\right) \\
\mathrm{h}: \text { 厚さ } \quad\left(=30 \times 10^{-6} \mathrm{~m}\right) \\
\rho: \text { 密度 } \quad\left(=4.5 \times 10^{3} \mathrm{~kg} / \mathrm{m}^{3}\right) \\
\mathrm{D}: \text { 曲げ剛性 }\left(=\frac{\mathrm{E} \mathrm{h}}{12\left(1-\nu^{2}\right)}\right)
\end{aligned}
$$

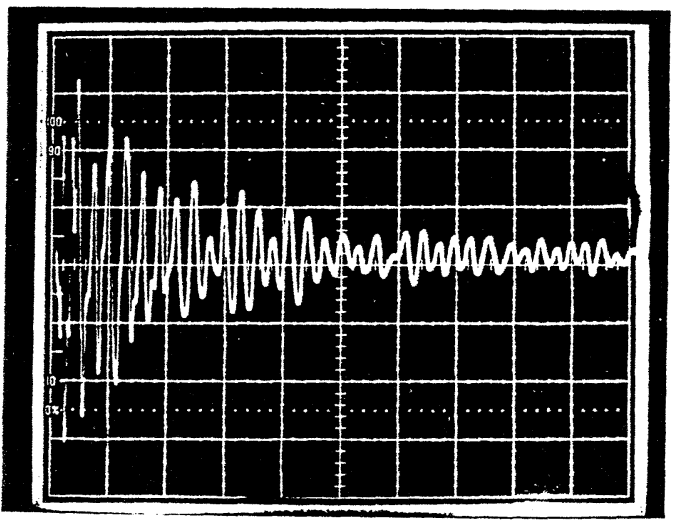

\section{Photo 5}

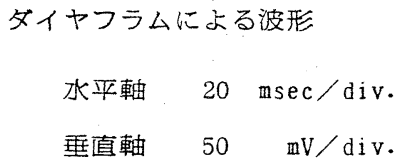

室 温 


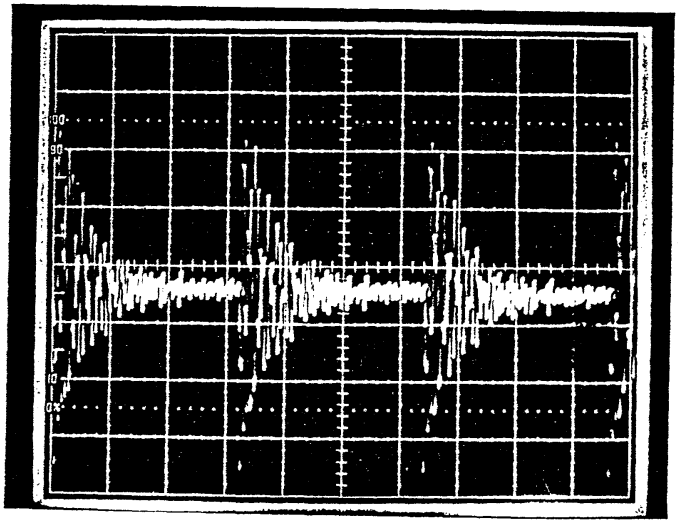

\section{Photo 6}

ダイヤフラムによる波形

$$
\begin{aligned}
& \text { 水平軸 } 0.1 \mathrm{sec} / \mathrm{div} . \\
& \text { 垂直軸 } 50 \mathrm{mV} / \mathrm{div} . \\
& \text { ヒーム条件 }
\end{aligned}
$$

4. $5 \mu \mathrm{sec}$,

3. $25 \mathrm{p} \mathrm{p} \mathrm{s}$

室 温

$$
\begin{aligned}
& \mathrm{E}: \quad \text { ヤング率 }\left(=11.57 \times 10^{10} \mathrm{~N} / \mathrm{m}^{2}\right) \\
& \nu: \quad \text { ポアソン比 }(=0.321)
\end{aligned}
$$

上に揭げた数値を代入して, $\mathrm{f}=142 \mathrm{~Hz}$ を得た。この值と実験による值を比較すると，実験によっ て得られた波形は, $\mathrm{Ti}$ 膜の固有振動波形と考えられる。また Ti 膜ダィヤフラムの, 圧力に対する出 力の校正をしていないため, 圧力の絶対值を読み取るてとはできない。

Photo 6 は, ビーム条件が, パルス幅 $4.5 \mu \mathrm{sec}, 3.25 \mathrm{pps}$ ( 1 秒間に 3.25 回の繰返しパルス) で照射した場合の写真である。時間軸は $0.1 \mathrm{sec} / \mathrm{div}$ てであり， 1 秒間に約 3 つのピークが見られる。 ての写真より, てのダィャフラムによる測定は, 周波数としては応答性に問題があるものの, 圧力感 度としては良好であるといえる。

\section{4. 考 察}

本実験により，以下のような知見を得た。

○圧力変換器を用いた場合, 水銀中の圧力波の速度に関して, 実験結果は, 計算值とよい一致を示 した。圧力值については, 微小信号のために読み取りができなかった。

○本実験で用いたダィヤフラム検出器の場合, ダイヤフラムの固有振動により, 周波数に関しては 問題があるが, 感度としては良好であるてとがわかった。

以上, 限られたマシンタイムの中で, $2 \sim 3$ の測定法を試みたが, 圧力が小さく, かつ周波数が高 い信号の検出について, 今後, 検討を進めなければならない。また, 解析の作業も進めていく計画で ある。 